\title{
大片段缩合法合成 DNA
}

本文报道用大片段缩合法合成 DNA 的 新方法. 该方法的原理是：用固相亚磷酰胺 方法合成 DNA 片段，以氢氧化钠的乙醇、水 混合溶液选择性地水解连于 CPG 载体与 DNA 片段之间的酯键，得到 $3^{\prime}$ 端羟基游离 的并保留保护基的 DNA 片段; 将连于 CPG 载体上的 DNA 片段 $5^{\prime}$ 端羟基磷酰化，然后 与前述 DNA 片段在四唑二异丙胺盐存在下 进行缩合, 得到了长度为两片段之和的大片 殿. 重复上述过程可能获得更大的 DNA 片 段。这种方法的应用可能提高现有合成 DNA 的能力, 并为用化学法直接合成某些多肽的 基因提供一条新的途径.

我们用甲氧基亚磷酰二异丙胺保护脱氧 核葉单体于 DNA 自动合成仪上合成了两个 分别为 31 和 40 个碱基长度的 DNA 片段, 将它们按上述方法进行缩合。通过测定片 段缩合前后脱 $5^{\prime}$ 端羟基保护基 DMT 液体的 $498 \mathrm{~nm}$ 吸收值,计算其缩合产率达 $21 \%$ ，将 缩合后的 DNA 大片段氨解脱保护基后，用 $r^{32}$ P-dATP 标记其 $5^{\prime}$ 末端，走 $16 \%$ 聚丙烯 酰胺胶 $(7 \mathrm{~mol} / \mathrm{L}$ 腿) 电泳，放射自显影,结

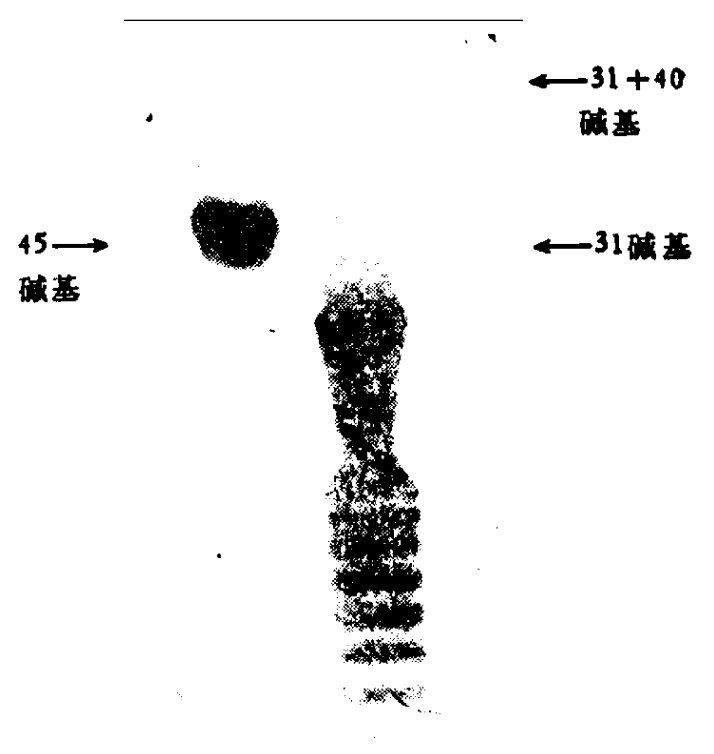

图 1 缩合物放射自显影图

果见图 1, 在相当于两片段之和的位置出现 了放射性条带，表明有缩合产物生成。

高必峰

(中国医学科学院基础医学研究所, 北京)

闵永洁 施文王启松

（次且大学遭传学研究所,上海）

\section{放射土壤杆菌 E26 有效抑制荡萄冠瘁瘦的形成}

淢萄冠瘿病是由生物 3 型根癌土壤杆菌 (Agrobacterium tumefaciens) 引起的. 这 种病原菌对放射土壤杆菌 K84 菌株产生 的 农杆菌䒺 (Agrocin) 不敏感。最近我们从蒱 淢冠疾㽷中分离出一株产农杆菌素不致病的 生物 3 型土壤杆菌，经鉴定命名为放射土塯 杆菌 (A. radiobacter) E26, 对苚萄根㾂土

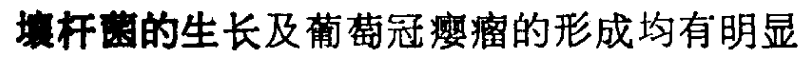
的㧕制作用。

E26 菌株具有生物 3 型土壤杆菌的生理 生化特性。对荡萄及其他受试植物均不致 病。按琞 Stonier（1960）法，用改良 AB 洋 莱培茲蕉平血测定 E26 对病原菌的抑制，所
试的 20 株有代表性的生物 3 型和 1 株 生 物 1 型葡萄根癌土壤杆菌, 均能为 E26 菌株所 产生的农杆菌素所抑制。对含胭脂碱、章鱼 碱或农杆碱 $\mathrm{Ti}$ 质粒的其他生物 1 型和 2 型 根癌土壤杆菌，如 C58、K27、702、pt12、A6、 Bo542 等菌株亦有不同程度抑制.

在温室接种试验中, E26 菌株和不同类 型的致病力强的淢萄根癌土壤杆菌混合，[阔 时接种到感病的惐得嫩枝和向日䓵幼苗苍 上,成功抑制病原菌 (18 株为章鱼碱 $\mathrm{Ti}$ 质柆 型，1株胭脂碱，一株䞍氨酸型)在上述植物 形成冠疼溜. 这结果与平血上敏感栍测定的 结果相符合. 
E26 菌株接种在落萢枝条上, 一个月后 仍能分离出大年接种物, 表明它能在植株伤 口附近定殖，产生农杆菌紊，竞争抑制根癌 土坮杆菌的僈人。'此外,消除了 $\mathrm{Ti}$ 质粒的根 豈土流杆菌对农杆菌亲 E26 也敏感，推测病 原囷对 E26 敏感性编码基因可能在染色体

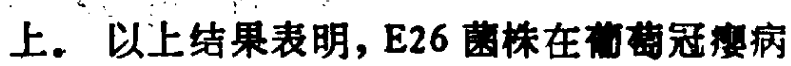
的生物防治中有应用前景.

\section{梁亚杰 狄原就”赵家英马德钦 （中国科学院机生物研究所，北京; \\ “北京农业大学植保系)}

\section{鱼斯复眼光感受器生理变化作为时间和适应状态的函数 *}

本文利用电生理细胞内记录方法, 在 $24 \mathrm{~h}$ 周期(日间和夜间)内和不同适应（明适应和 暗适应)状态下,持续记录. 研究了滀斯复眼 侧区小眼小网膜细胞的角灵敏度、光谱灵敏 度、偏振光灵敏度、绝对灵敏度和适应变化 的时间过程, 有关斯复眼的研究未见报 道.

1. 小网膜细胞的角灵敏度, 小网膜细胞 反应的幅度在给定的光强度下随着刺激光点 在细胞视场内位置的变化而变化. 当刺潡光 点在细胞光轴上时, 反应最大. 记录 20 个小 网膜细胞的平均值, 日间暗适应状态下, 水 平方向和垂直方向的平均接受角分别为 $2.2^{\circ}$ 和 $2.1^{\circ}$; 日间明适应状态下, 水平方向和垂 直方向的平均接受角分别为 $1.7^{\circ}$ 和 $1.6^{\circ}$. 夜 间暗适应状态下, 水平方向和垂直方向的平 均接受角分别为 $3.1^{\circ}$ 和 $2.9^{\circ}$; 夜间明适应状 态下, 水平方向和垂直方向的平均接受角分 别为 $2.0^{\circ}$ 和 $1.8^{\circ}$.

2. 小网膜细胞的光谱灵敏度, 日间和夜 间暗适应状态下 12 个小网膜细胞的光谱灵 敏度都有一个宽图的绿色波长峰 值 530 $550 \mathrm{~nm})$ 和一个小的紫外次峰值 $(370 \mathrm{~nm})$.

3. 小网膜细胞的偏振光灵敏度, 日间和 夜间暗适应状态下, 2 个小网膜细胞的偏振 光灵敏度值 (PS) 分别为 2.6 和 4.1, 这说明 都有偏振光灵敏度, 而且夜间更大. 这可能 因为全斯复眼光感受器结构上遵循一个生理 节律的变化, 日间, 光感受器的感杆束微线
毛破碎、脱落和变细短, 感杆束发生较大扭 转; 而夜间,由于感杆束微线毛重新生长、组 装和变粗长, 感杆束变得较小扭转. 感杆束 的偏振光灵敏度同它的扭转角度密切相关.

4. 小网膜细胞的绝对灵敏度, 20 个小网 膜细胞在日间和夜间,在明适应和暗适应时, 细胞反应的幅度是不同的. 日间小网膜细胞 反应的幅度小于夜间反应的幅度, 明适应时 的小网膜细胞反应幅度小于暗适应时的反应 幅度, 这就意味着小网膜细胞对光的绝对灵 敏度不同，夜间暗适应的小网膜细胞对光很 灵敏,显示了较高的绝对灵敏度.

5. 小网膜细胞适应变化的时间过程, 追! 踪一种适应状态到另一种适应状态的时间过 程, 就是从明适应状态到暗适应状态或者相 反的过程. 2 个小网膜细胞的接受角和绝对 灵敏度变化的时间过程表明，从完全暗适应 到完全明适应的时间过程快于相反的过程. 也就是从完全明适应状态过渡到完全暗适应 状态的时间过程大约需要 $1 \mathrm{~h}$, 而相反过程大 约需要 $0.5 \mathrm{~h}$.

\section{吴卫国 吴梅英 E. J. Warrant} 徐智敏石淑王翔 高奔张少吾

（中国科学院生物物理研究所，北京; 影大 利亚国立大学被觉科学中心，塂培位）

“国家自然科学基金助项目.

报 1989 年 